\title{
TINJAUAN KONSEP DIRI DAN DIMENSINYA PADA ANAK DALAM MASA KANAK-KANAK AKHIR
}

\author{
Beatriks Novianti Kiling \\ Psikologi Perkembangan, Pendidikan Anak Usia Dini \\ Fakultas Keguruan dan Ilmu Pendidikan, Program Studi Pendidikan Anak Usia Dini \\ Universitas Nusa Cendana \\ email:boenga.eve@gmail.com \\ Indra Yohanes Kiling \\ Psikologi Komunitas \\ Peneliti Institute of Resource Governance and Social Change \\ email: iykiling@gmail.com
}

\begin{abstract}
Individual self-concept is manifested in things that is related to that individual. View about one's self, self-evaluation, and expectation to one's self form this individual self-concept. Awareness of self-concept from the view of psychology would help a good and positive self-concept. This positive self-concept would in turn develop positive behaviours and interactions in daily life. This paper discuss the concept of self-concept from psychological literatures and perspective. Dimensions, aspects, and factors of selfconcept would be discussed and related to children's situation in late childhood phase. Parents, teachers, and also the surrounding environment have important role in shaping self-concept of children. Social support and also positive behavior model from these children's closest persons and also the community will help create positive self-concept that in turn will support the transition to teenager phase. This paper hopefully will be able to stimulate researcher to conduct further relevant research concerning children's selfconcept.
\end{abstract}

Keywords: self-concept, children, late childhood

\begin{abstract}
Abstrak. Konsep diri seseorang tergambarkan dalam hal-hal yang berkaitan dengan individu tersebut. Pandangan terhadap diri sendiri, hasil evaluasi diri, serta harapan terhadap diri sendiri membentuk konsep diri individu. Pemahaman terhadap konsep diri dari sudut pandang psikologi akan membantu untuk membentuk konsep diri yang baik. Konsep diri yang positif kemudian akan membentuk perilaku dan interaksi yang positif pula dalam kehidupan. Makalah ini membahas konseptual konsep diri ditinjau dari literatur psikologi. Dimensi, aspek dan faktor konsep diri didiskusikan dan dikaitkan dengan keadaan anak dalam masa kanak-kanak akhir. Orangtua, guru, serta lingkungan masyarakat berperan penting dalam proses pembentukan konsep diri dari anak-anak pada masa kanak-kanak akhir. Dukungan serta contoh perilaku positif dari orang terdekat serta komunitas akan membantu pembentukan konsep diri yang positif yang nantinya dapat membantu anak untuk bertransisi ke fase remaja. Makalah ini diharap dapat membantu akademisi untuk melakukan penelitian terkait konsep diri anak.
\end{abstract}

Kata kunci: konsep diri, anak, masa kanak-kanak

\section{PENDAHULUAN}

Pembahasan mengenai konsep diri sudah dibicarakan sejak para filsuf mulai bertanya- tanya mengenai "diri”. William James, salah satu pelopor psikologi (Mussen dkk., 1979) mencoba menguraikan perbedaan dari "diri" yang menjadi 
sumber dikotomi. James membedakan diri menjadi dua komponen yaitu "aku objek" (me) dan "aku subjek" (I). "Aku objek" adalah keseluruhan diri seseorang yang dapat disebut miliknya, termasuk didalamnya kemampuan, karakteristik sosial dan kepribadian, serta kepemilikan materi. "Aku subjek" adalah diri sebagai yang mengetahui. "Me" dan "I" adalah diri global yang berlangsung bersamaan (Burns, 1979). Mereka merupakan aspek-aspek yang berbeda dari suatu kesatuan yang sama; pembedaan antara pengalaman yang murni (I) dan isi pengalaman (Me); antara pengenal dan yang dikenal.

Menurut James diri ini terdiri dari empat (4) komponen, yaitu: 1) Diri spiritual; 2) Diri kebendaan; 3) Diri sosial dan 4) Diri badaniah. Diri spiritual menyangkut kepuasan terhadap apa yang telah kita lakukan, bukan terhadap apa yang kita punyai. Diri kebendaan terdiri atas pakaian dan milik-milik kebendaan yang kita lihat sebagai bagian dari kita. Diri sosial adalah segala sesuatu yang berhubungan dengan orang lain. Setiap individu memiliki banyak diri-diri sosial yang berbeda-beda, sebanyak individu-individu dan group-group yang dianggap penting. Diri badaniah ditempatkan terakhir. Diri badaniah berkaitan dengan kondisi fisik seseorang, seperti tinggi, gemuk, pendek, berotot, mancung atau pesek, kulit terang atau gelap, rambut lurus atau keriting.

Hal senada mengenai konsep diri dikemukakan oleh Cooley pada tahun 1902 (Burns, 1979). Cooley menambahkan masyarakat sebagai faktor penting dalam pembentukan konsep diri seseorang. Baginya umpan balik yang diintrerpretasikan secara subjektif dari orang-orang lain merupakan sumber data utama mengenal diri. Teorinya yang terkenal adalah looking-glass-self (Johnson dan Medinnus, 1974), yaitu bagaimana konsep diri seseorang dipengaruhi oleh pendapat orang lain terhadap dirinya. Kaca cermin memantulkan evaluasievaluasi yang dibayangkan orang lain tentang kita. Dengan kata lain, konsep diri merupakan hasil dari penilaian atau evaluasi terhadap diri sendiri dan pendapat orang lain mengenai dirinya sendiri.

Pemikiran Cooley kemudian ditindak lanjuti oleh George H. Mead pada tahun 1934 (Johnson \& Medinnus, 1974). Bagi Mead, konsep diri tergantung dari kelompok sosial yang ia masuki (Burns, 1979). Dalam interaksi sosial itu individu memperhatikan bagaimana reaksi orang lain terhadapnya. Dengan demikian individu dapat mengantisipasi reaksi orang lain tersebut dengan perilaku yang pantas dan individu juga belajar bagaimana lingkungan bereaksi terhadapnya. Mead (dalam Wyse, 2004), menulis bahwa konsep diri terbentuk berdasarkan perbandingan sosial yang dilakukan individu. Perbandingan sosial yang dimaksud adalah kita membandingkan diri kita dengan orang-orang yang dianggap penting dan menggunakan informasi tersebut untuk membangun konsep tentang diri kita.

$$
\text { Rogers dalam Burns }
$$

mendefenisikan konsep diri sebagai kesadaran yang tetap, mengenai pengalaman-pengalaman yang berhubungan dengan Aku dan membedakan aku dari yang bukan aku. Menurutnya dalam Hurlock (1999), membagi konsep diri menjadi dua bagian yaitu konsep diri sebenarnya/ rill dan konsep diri ideal. Konsep diri sebenarnya ialah konsep seseorang dari siapa dan apa dia itu. Konsep ini merupakan bayangan cermin, ditentukan sebagian besar oleh peran dan hubungan dengan orang lain, dan apa yang kiranya reaksi orang lain terhadapnya. Konsep diri ideal ialah gambaran seseorang mengenai penampilan dan kepribadian yang didambakan. Rogers (Alwisol, 2012) mengenalkan dua konsep lagi untuk menunjukkan apakah kedua konsep diri tersebut sesuai atau tidak, yaitu incorgruence dan congruence. Incongruence adalah ketidak cocokan antara self yang dirasakan dalam pengalaman aktual disertai pertentangan dan kekacauan batin, sedangkan congruence berarti situasi yang merupakan pengungkapan pengalamandiri dengan seksama dalam sebuah konsep diri yang utuh, integral dan sejati. Menurutnya pribadi yang berfungsi sepenuhnya adalah pribadi yang mengalami penghargaan positif tanpa syarat.

Menurut Susana (2007) konsep diri yang sehat tidak sekedar positif, tetapi merupakan gambaran tentang diri yang sesuai dengan kenyataan dirinya (real self). Apabila gambaran tentang dirinya, terutama diri yang dicita-citakan (ideal self) tidak sesuai dengan kenyataan dirinya, maka akan terjadi kesenjangan antara diri yang dicita-citakan dengan kenyataan dirinya. Kesenjangan ini akan menimbulkan perasaan tidak nyaman dalam diri seseorang. Semakin besar kesenjangan, semakin besar pula rasa tidak nyaman yang ditimbulkan. 
Ada dua jenis konsep diri negatif (Calhoun \& Acocella, 1990). Pertama, pandangan seseorang tentang dirinya sendiri benar-benar tidak teratur, dia tidak memiliki perasaan kestabilan dan keutuhan diri. Dia benarbenar tidak tahu siapa dia, apa kekuatan dan kelemahannya, atau apa yang dihargai dalam hidupnya. Kedua, konsep dirinya hampir merupakan lawan dari yang pertama. Disini konsep diri itu terlalu stabil dan terlalu teratur, dengan kata lain terlalu kaku. Mungkin karena dididik dengan sangat keras, individu tersebut menciptakan citra diri yang tidak mengijinkan adanya penyimpangan dari seperangkat hukum besi yang dalam pikirannya merupakan cara hidup yang tepat. Tipe ini menerima informasi baru sebagai ancaman dan menjadi sumber kecemasan. Berkaitan dengan evaluasi diri, konsep diri yang negatif menurut defenisinya meliputi penilaian negatif terhadap diri. Apapun yang dilakukan tidak memberi kepuasan terhadap dirinya. Apapun yang diperolehnya tampaknya tidak berharga dibandingkan dengan apa yang diperoleh orang lain.

Konsep diri yang positif merupakan bentuk dari penerimaan diri. Orang dengan konsep diri positif mengenal dirinya dengan baik sekali (Wicklund dan Frey (Calhoun \& Acocella, 1990). Orang dengan konsep diri positif bersifat stabil dan bervasiasi. Mereka dapat memahami dan menerima sejumlah fakta yang sangat bermacam-macam tentang dirinya sendiri. Berkaitan dengan pengharapan, orang dengan konsep diri positif merancang tujuan-tujuan yang sesuai dan realistis.

Uraian-uraian mengenai konsep diri diatas, semuanya mengarahkan konsep diri kepada hal-hal yang berkaitan dengan individu itu sendiri, yang didalamnya mencakup pandangannya terhadap dirinya, apa yang ia peroleh dari hasil evaluasinya terhadap yang orang lain lakukan, katakan terhadap dirinya. Hasil dari apa yang ia ketahui, yang ia harapkan dan ia evaluasi itu dapat berupa fisik, emosi, sosial maupun spiritual. Konsep diri akan dikupas lebih lanjut dalam tulisan ini dalam konteks anak.

Dimensi Konsep Diri.Pengertianpengertian yang kemudian dikembangkan oleh para ahli seperti yang dijelaskan diatas mengenai konsep diri, dapat terlihat bahwa konsep diri sebenarnya mencakup beberapa dimensi didalamnya. Ada beberapa dimensi yang terkandung dalam konsep diri, yaitu pengetahuan seseorang tentang dirinya, pengharapan mengenai dirinya (descriptive) dan penilaian (evaluative) tentang diri sendiri (Calhoun \& Acocella, 1990). Berikut ketiga dimensi ini akan dibahas rinci :

a) Dimensi pengetahuan

Dimensi ini adalah tentang apa yang seseorang ketahui mengenai dirinya sendiri seperti usia, jenis kelamin, kebangsaan, suku, pekerjaan dan lainnya. Faktor-faktor tersebut menempatkan individu kepada suatu kelompok sosial seperti kelompok umur, suku bangsa, dan sebagainya. Akhirnya individu tersebut mengidentifikasikan dengan kelompok sosial tersebut yang menambah daftar julukan kita, seperti kelompok menengah atas, kelompok wanita karir dan lainnya. Julukan-julukan ini berganti setiap hari dan setiap individu tersebut menerima julukan baru, ada informasi baru yang diterima yang individu tersebut masukan ke dalam potret diri mentalnya.

b) Dimensi Harapan

Rogers (Calhoun dan Acocella 1990) mengemukakan bahwa pada saat individu memiliki satu set pandangan tentang siapa kita, kita juga mempunyai satu set pandangan lain yaitu tentang kemungkinan kita menjadi apa dimasa mendatang. Artinya individu tersebut memiliki pengharapan bagi dirinya sendiri dan pengharapan ini merupakan diri-ideal. Diri ideal ini berbeda setiap individu. Apapun harapan setiap individu, semuanya membangkitkan kekuatan yang mendorong menuju masa depan dan memandu kegiatan individu dalam perjalanan hidupnya.

c) Dimensi Penilaian

Ini merupakan penilaian terhadap diri sendiri (Marsh dkk., 1983). Setiap individu berkedudukan sebagai penilaian tentangnya diri sendiri setiap hari, mengukur apakah kita bertentangan dengan a) saya-dapat-menjadi-apa, yaitu pengharapan individu bagi dirinya sendiri; b) saya-seharusnya-menjadi-apa. Hasil pengukuran tersebut disebut rasa harga diri. Rogers menilai bahwa semakin besar ketidaksesuaian antara gambaran kita mengenai siapa kita dan gambaran tentang seharusnya kita menjadi apa atau dapat menjadi apa, akan semakin rendah rasa harga diri kita.

Aspek Konsep Diri.Konsep diri terbagi atas beberapa bagian. Atwater dalam Puspasari (2007), mengolongkannya dalam lima bagian, 
setelah melakukan penelitian panjang tentang konsep diri, yaitu pola pandang diri subjektif (subjective self), bentuk dan bayangan tubuh (self image), perbandingan ideal (the ideal self), pembentukan diri secara sosial (the social self) dan skala-skala konsep diri:

a) Pola pandangan diri subjektif (Subjective self)

Cara pengenalan diri yang terbentuk dari bagaimana individu melihat dirinya sendiri. Biasanya secara umum diri yang dipikirkan itu terdiri dari gambaran-gambaran diri (self image) baik itu potongan visual (seperti bentuk wajah dan tubuh yang diamati ketika bercermin), persepsi diri (umumnya didapati melalui bentuk komunikasi terhadap diri sendiri ataupun pengalaman bersosialisasi dengan orang lain). Dengan pemahaman konsep diri, seseorang akan membandingkan dirinya dengan orang lain dalam berbagai hal baik itu bersifat nonfisik.

Salah satu proses yang berkaitan dengan perbandingan nonfisik adalah proses perbandingan perspektif. Perbandingan ini dilakukan seseorang untuk melihat karakteristik dirinya dalam mengembangkan diri, seperti tingkat kemampuan komunikasi, tingkat kemampuan untuk menarik perhatian lawan jenis atau lainya. Tentunya mekanisme pengenalan diri nyata dan perseptif tidak dapat dipisahkan. Proses pengenalan diri yang bersifat nyata mempengaruhi persepsi diri kita. Misalnya seseorang yang melihat bayangan dirinya pada cermin secara nyata kemudian secara langsung akan mempengaruhi persepsi dirinya.

b) Bentuk dan Bayangan Tubuh (Body Image)

Berbeda dengan mekanisme yang sebelumnya, bahwa bayangan tubuh dicermin mempengaruhi persepsinya, sebaliknya yang kedua ini adalah kondisi emosional dapat memberi pengaruh terhadap bagaimana seseorang mengenali bentuk fisiknya. Misalnya pengalaman traumatis yang beresiko besar seperti pelecehan seksual atau kekerasan fisik maupun psikologis lainnya. Korban pada umumnya akan memiliki konsep diri yang negatif pada tubuhnya.

c) Perbandingan Ideal

Salah satu proses pengenalan diri adalah dengan membandingkan diri dengan sosok ideal yang diharapkan. Proses pembentukan diri ideal ini melalui proses-proses seperti adanya pembentukan harapan diri seperti ingin menjadi cantik atau lebih pandai, persyaratan moral, seperti kejujuran, ketaatan beribadah dan tingkah laku terhadap orangtua. Misalnya anak yang tinggal pada lingkungan yang sangat religious, kemungkinan besar akan memiliki konsep diri yang sangat tinggi pada kejujuran. Menurut Keliat dalam Salbiah (2003), agar individu mampu berfungsi dan mendemonstrasikan kecocokan antara persepsi diri dan ideal diri, idela diri hendaknya ditetapkan tidak terlalu tinggi, tetapi masih lebih tinggi dari kemampuan agar menjadi pendorong dan masih dapat dicapai.

d) Pembentukan Diri Secara Sosial (The Social Self)

Proses ini merupakan proses melihat diri seperti yang dirasakan orang lain. Seseorang mencoba untuk memahami persepsi orang lain terhadap dirinya. Pembentukan konsep diri ini melibatkan penilaian sekelompok terhadap suatu individu. Penilaian sekelompok orang inilah yang merupakan proses labelisasi terhadap karakteristik konsep diri seseorang. Proses labeling ini, misalnya memanggil anak dengan nama si gendut, bandel, tukang berkelahi. Pemberian label ini dilakukan berdasarkan persepsi orang terhadap apa yang kelihatan, baik fisik maupun non fisik. Keliat dalam Salbiah (2003) memasukan peran dan identitas dalam pembentukan diri secara sosial.

e) Skala-skala Konsep Diri

Konsep diri melalui sejarah perkembangan yang cukup panjang, yang meliputi: 1) model terdahulu yang berisikan riset tentang konsep diri sebagai sesuatu yang terdiri dari banyak segi (multifaceted) (Marsh dkk., 1984); 2) Model Shalvelson yang berisikan tentang model konsep diri yang bersifat terorganisasi atau terstruktur, terdiri dari banyak segi (multi-faceted), bersifat hirarkis (dalam hirarki terdapat puncak yang stabil, namun untuk hirarki di bawahnya menjadi kurang stabil sebagai konsekuensi adanya konsep diri pada suatu situasi yang spesifik), bersifat evaluatif maupun deskriptif dan berbeda dari konstruk yang lain (Byrne \& Darlene, 1996); 3) model Shalvelson dan Marsh (Marsh dkk., 1983). Berikut model konsep diri umum yang diajukan Shalvelson, Hubner dan Stanton (Song dan Hattie 1984) : 




Gambar 1. Model Konsep Diri oleh Shalvelson, Hubner dan Stanon (Song \& Hattie, 1984)

Bagi Shalvelson (Marsh dkk., 1984), konsep diri ini sangat multi dimensi dan bergerak secara hirarki. Dimulai dari konsep diri akademik (matematika dan membaca) dan kemudian ke konsep diri secara umum. Konsep diri ini kurang multifaced seiring dengan dengan perkembangan individu, bayi menjadi dewasa dan tergantung juga dengan sistem lain yang individu terima dalam kelompok.

Shalvelson menetapkan skala yang lengkap mengenai konsep diri (Marsh dkk., 1983). Skala ini secara deskriptif menjabarkan aspek-aspek dari konsep diri anak sebagaimana ditampilkan pada tabel 1:

\begin{tabular}{|l|l|}
\hline \multicolumn{1}{|c|}{ ASPEK } & \multicolumn{1}{c|}{ DESKRIPSI } \\
\hline Kemampuan fisik & $\begin{array}{l}\text { Kemampuan dan minat yang berkaitan dengan } \\
\text { olahraga maupun aktivitas fisik lainnya }\end{array}$ \\
\hline Penampilan Fisik & Sejauh mana seseorang memiliki fisik yang menarik. \\
\hline Hubungan dengan lawan jenis & $\begin{array}{l}\text { Interaksi dengan sahabat seumur yang memiliki jenis } \\
\text { kelamin berbeda }\end{array}$ \\
\hline Hubungan dengan sesama jenis & $\begin{array}{l}\text { Interaksi dengan sahabat seumur yang memiliki } \\
\text { kesamaan jenis kelamin }\end{array}$ \\
\hline Hubungan antara anak dengan orangtua & Interaksi anak dengan orangtua \\
\hline Matematika & $\begin{array}{l}\text { Kemampuan, rasa suka, dan ketertarikan pada } \\
\text { matematika dan ilmu logika }\end{array}$ \\
\hline Verbal & $\begin{array}{l}\text { Kemampuan, rasa suka dan ketertarikan pada bahasa, } \\
\text { khususnya bahasa inggris dan membaca }\end{array}$ \\
\hline Sekolah secara umum & $\begin{array}{l}\text { Kemampuan, rasa suka dan ketertarikan pada subjek- } \\
\text { subjek yang berkaitan dengan sekolah }\end{array}$ \\
\hline Konsep diri secara umum & $\begin{array}{l}\text { Kemampuan untuk menghargai diri sendiri dan } \\
\text { membangun rasa percaya diri }\end{array}$ \\
\hline
\end{tabular}

Tabel 1. Aspek Konsep Diri menurut Shalvelson

\section{Faktor-faktor yang mempengaruhi Konsep Diri}

Konsep diri tidaklah terjadi begitu saja, tetapi berkembang secara bertahap seiring dengan tingkat perkembangan individu tersebut. 
Berbagai faktor dapat mempengaruhi pembentukan konsep diri seseorang. Struat dan Sudden dalam Salbiah (2003) mengemukakan beberapa faktor yang mempengaruhi pembentukan konsep diri yaitu teori perkembangan tentang konsep diri, significant other dan self-perception.

a) Teori perkembangan konsep diri

Konsep diri belum ada waktu lahir, kemudian berkembang secara bertahap mulai mengenal dan membedakan dirinya dengan orang lain. Kesadaran dirinya baru muncul pada tahun kedua kehidupannya. Pada usia 18 bulan anak mulai mengenai wajah mereka sendiri dan menunjukkan gambar mereka sendiri ketika disebutkan namanya (Damon \& Hart dalam Mussen dkk., 1979). Awal kehidupannya, bayi belum dapat membedakan dirinya. Umur 3-6 tahun anak mulai merasa ada perbedaan diri dengan orang lain, tetapi gagal membedakan antara perspektif sosial (pemikiran, perasaan) orang lain dan perspektif diri sendiri (Santrock, 1999). Piaget mengindentifikasikan bahwa pada awalnya bayi dalam keadaan undifferentiated absolute dimana tidak ada batas antara pengertiannya tentang tubuh dan objek-objek lainnya, diantara realitas dan fantasi; tetapi secara betahap dia akan membuat perbedaanperbedaan yang jelas antara apa yang dirinya dan apa yang bukan dirinya (Burns, 1979).

b) Significant Other (orang-orang yang penting atau yang terdekat)

Significant other yaitu suatu kondisi dimana individu belajar untuk memahami penilaian orang lain terhadap dirinya (Puspasari, 2007). Seperti yang dikatakan diatas, bahwa konsep diri dipelajari melalui kontak dan pengalaman dengan orang lain, belajar diri sendiri melalui cermin orang lain yaitu dengan cara pandangan bahwa diri merupakan interpretasi diri pandangan orang lain terhadap diri. Konsep diri biasanya diukur dengan jalan meminta orang mendeskripsikan dirinya atau dengan menceritakan bagaimana ia berbeda dengan orang lain (Mussen dkk., 1979). Anak sangat dipengaruhi oleh orang yang dekat dengannya yaitu orangtua. Orangtua adalah kontak sosial yang paling awal yang kita alami, dan yang paling kuat. Bayi bergantung pada orangtuanya untuk makanan, perlindungan dan kenyamanannya, akibatnya orangtua menjadi sangat penting dimata anak. Apa yang dikomunikasikan oleh orangtua lebih menancap daripada informasi lain yang anak terima
(Calhoun \& Acocella, 1990). Coopersmith dalam Calhoun dan Acocella (1990) mengemukakan bahwa perasaan nilai anak sebagai "seseorang" berasal dari nilai yang diberikan orangtua kepada mereka. Orang terdekat anak lainnya adalah ketika anak mulai meluaskan jaringan pergaulannya, yaitu teman sebaya. Kelompok ini menjadi urutan kedua setelah orangtua yang potensinya besar dalam mempengaruhi pembentukan konsep diri. Awalnya anak merasa cukup dan puas dengan cinta yang mereka dapatkan lewat orangtua dirumah, tetapi kemudian kebutuhan akan cinta anak-anak lain dikelompok dibutuhkan. Hal yang menjadi masalah jika anak tidak diterima oleh teman kelompoknya, maka konsep dirinya akan terganggu. Penerimaan teman merupakan elemen yang penting dalam konsep penerimaan diri anak. Anak yang ditolak dalam kelompoknya akan menyimpan dendam dan membangun rasa marah yang besar untuk mengurangi stressnya ketika ditolak (Johnson \& Medinnus, 1974). Selain penerimaan dan penolakan teman dalam kelompok, peran yang diukir anak dalam kelompok teman sebayanya mungkin mempunyai pengaruh yang dalam pada pandangannya tentang dirinya sendiri (Calhoun \& Acocella, 1990).

c) Self Perception (persepsi diri sendiri)

Yaitu persepsi individu terhadap diri sendiri dan penilaian, serta persepsi individu terhadap pengalamannya akan situasi tertentu. Konsep diri dapat dibentuk melalui pandangan diri dan pengalaman yang positif, sehingga konsep merupakan aspek yang kritikal dan dasar dari perilaku individu. Individu dengan konsep diri yang positif dapat dilihat dari kemampuan interpersonal, kemampuan intelektual dan penguasaan lingkungan. Sebaliknya konsep diri yang negatif dapat dilihat dari hubungan individu dan sosial yang terganggu.

Hal senada dikemukakan Burns (1979), namun Burns membedakannya dalam 4 sumber pembentukan konsep diri, yaitu diri fisik dan citra tubuh, bahasa, umpan balik dari lingkungan dan pola asuh.

\section{a) Diri fisik dan citra diri}

Merupakan evaluasi terhadap kondisi fisiknya. Bagi Burns (1979) bentuk tubuh, penampilan dan ukuran tubuh merupakan hal yang penting dalam menjelaskan perubahan konsep diri seseorang. Stuart dan Sudden (dalam Salbiah, 2003) mendefenisikan citra diri sebagai 
sikap seseorang terhadap tubuhnya secara sadar dan tidak sadar. Sikap ini menyangkut persepsi dan perasaan tentang ukuran, bentuk, fungsi penampilan dan potensi tubuh saat ini dan masa lalu secara berkesinambungan dimodifikasi dengan pengalaman baru setiap individu.

Menurut Burns (1979) konsep diri mulanya adalah citra tubuh. Perasaan-perasaan anak yang bersangkutan dengan tubuh dan citra tubuh menjadi inti konsep diri dalam tahun-tahun pertama kehidupan anak. Pada awal kehidupan individu, perbedaan yang dipikirkan mengenai dirinya dengan lingkungan didasarkan pada sensasi-sensasi sentuhan, otot dan kinestiknya sendiri saat ia menyentuh, mencubit, melempar, jatuh, menubruk. Sewaktu pengendalian tubuh anak menjadi lebih efisien, anak belajar menguasai dunia fisiknya. Keberhasilan anak ini membawa anak pada kegiatan fisik yang lebih luas dan tentunya anak mulai bersentuhan dengan orang lain selain dirinya sendiri. Hal ini tentunya menghasilkan konsep diri yang akan membantu anak dalam pergaulannya mendatang.

Citra diri menurut Kihlstrom dan Cantor dalam Calhoun dan Acocella (1990) adalah gambaran mental individu dan penilaian terhadap badannya sendiri, yang merupakan bagian integral dari konsep diri. Lanjutnya citra diri umumnya dibentuk dengan membandingkan nilai fisik dengan standart keindahan dari kebudayaan tertentu. Hasil penelitian menunjukkan bahwa laki-laki yang berbahu bidang, berotot dan wanita yang mempunyai proporsi tubuh yang bagus berkemungkinan mendapatkan persetujuan sosial, sehingga berkemungkinan juga memiliki konsep diri yang lebih positif (Burns, 1979).

Pada seorang anak, konsep diri tidak disebabkan oleh tipe tubuh, namun akibat umpan balik yang diberikan orang terdekatnya seperti pemberian label "si gembrot, si kurus kering, si kuping gajah". Pemberian label secara fisik pada masa kanak-kanak ini berbahaya bagi pembentukan konsep dirinya. Anak-anak sekolah dasar lebih menerima input yang berasal dari teman dan orang dewasa tentang dirinya dan prestasinya. Mereka lebih siap dan mempercayainya kemudian memasukannya menjadi kepribadiannya.

b) Bahasa

Menurut Burns (1979), kepentingan bahasa adalah sebagai alat yang mempermudah hubungan antar individu. Perasaan-perasaan seseorang disampaikan lewat bahasa. Konsep diri yang benar mungkin timbul pada saat bayi sadar bahwa dia punya nama, yang di permudah dengan bahasa. Simbol-simbol bahasa juga membentuk dasar dari konsepsi-konsepsi dan evaluasi-evaluasi tentang diri, misalnya sedang sedih, merasa bahagia.

c) Umpan balik dari orang-orang yang dekat

Teori umpan balik ini dikemukan oleh Cooley sebagai " the looking glass self " yaitu persepsi orang dekat mengenai diri kita (Puspasari, 2007). Orang-orang dekat ini adalah orangtua, saudara kandung, teman sebaya dan guru-guru. Lazimnya orangtua dianggap sebagai orang terdekat yang mempunyai pengaruh bagi perkembangan konsep diri anak. Namun berdasarkan penelitian yang dilakukan Kichner dan Vondraek pada tahun 1975 (Burns, 1979) terhadap 282 anak umur 3-6 tahun tentang orangorang yang menyenangkan, diperoleh bahwa teman sebaya/ sepermainan dan saudara kandung dianggap lebih menyenangkan daripada ibu atau ayah mereka. Pendapat orang-orang terdekat, sebagai hasil refleksi mereka mengenai diri kita, mempunyai arti penting bagi anak mengenai kemampuan mereka, sehingga berfungsi untuk mengurangi rasa aman, menurunkan perasaan tidak berdaya/ tidak mampu dan mengembangkan penghargaan terhadap diri anak. Setelah kehidupan anak meluas (masuk sekolah dasar), peran guru sebagai orang dekat anak sangat penting. Penelitian Staines tahun 1958 dalam Burns (1979) memperlihatkan dengan jelas bagaimana pengaruh teguran verbal dan non verbal terhadap perkembangan konsep diri anak. Komentar-komentar sehari-hari guru juga berpengaruh. Selain itu, sekolah sendiri juga memberikan model-model peran yang lain dari yang mereka dapatkan dalam keluarga dan teman sebayanya (Ganur, Bunga \& Kiling, 2014).

Jadi kuantitas umpan balik menjadi faktor penting dalam pertumbuhan konsep diri. Namun, kualitas umpan balik juga penting. Umpan balik yang konsisten juga penting. Seorang anak yang dibina dengan disiplin yang tidak konsisten akan kesulitan mengumpulkan perangkat aturan untuk menilai diri sendiri (Calhoun \& Acocella, 1990).

d) Praktek-praktek membesarkan anak

Ini berkaitan dengan pola asuh yang dikembangkan orangtua. Menurut Hurlock (1978) pola asuh dapat dimaknai sebagai suatu sistem yang diterima dan dipakai sebagai pedoman oleh orang tua dalam merawat, mendidik, melatih, membantu, dan memimpin anak.

Praktek-praktek membesarkan anak yang menekankan penghargaan, kehangatan dan 
penerimaan dikaitkan dengan disiplin yang tegas dan konsisten dapat meningkatkan harga diri anak yang berimplikasi pada konsep diri yang positif (Burns, 1979). Penelitian yang dilakukan Stott menunjukkan bahwa anak yang keluarganya sering ada konflik antar anggota keluarganya, memiliki kemampuan menyesuaikan diri yang kurang. Sedangkan hasil penemuan Coopersmith menunjukkan bahwa konsep diri positif akan muncul bila anak diperlakukan dengan penghargaan, diberikan standar yang didefenisikan dengan jelas dan baik (Burns, 1979).

\section{Konsep diri pada masa kanak-kanak akhir}

Bagi anak dalam masa kanak-kanak akhir, ia mulai belajar berpikir dan merasakan dirinya seperti apa yang telah ditentukan oleh orang lain dalam lingkungannya, misalnya orangtua, gurunya maupun teman-temannya. Bagaimana anak diperlakukan di rumah, di sekolah dan di masyarakat akan mempengaruhi pembentukan konsep dirinya (Hurlock, 2013). Bagaimana hubungan dengan orangtua, dengan saudara kandungnya, kedudukannya dalam keluarga (apakah ia anak pertama, anak tengah, anak bungsu, atau anak tunggal dari keluarga besar atau keluarga kecil) dan bagaimana pendapatnya mengenai cara-cara asuhan anak yang berlaku dalam keluarganya, semua ikut berperan dalam menentukan perkembangan konsep dirinya. Penelitian yang dilakukan Spilsbury (2002), melihat bagaimana anak yang tinggal di lingkungan yang penuh dengan perilaku kekerasan dan tingkat kriminal yang tinggi mempersepsi bahwa orang asing bisa melukai mereka jika mereka tidak hati-hati. Hal ini membuat anak mengembangkan konsep diri yang cenderung kurang percaya diri dan berhatihati yang termanifestasi dalam perilaku tidak berbicara dengan orang yang tidak dikenal.

Masih terkait pembentukan konsep diri pada masa kanak-kanak akhir, apabila seorang guru mengatakan secara terus-menerus pada seorang muridnya bahwa dia kurang mampu dalam kelas maka lama-kelamaan anak pada masa kanak-kanak akhir akan mempunyai konsep diri yang negatif dan 'kurang mampu' (Rais dalam Gunarsa \& Gunarsa, 2006). Terkait dengan hal ini, Adiyanti (2007) menyebutkan bahwa guru harus membantu anak dalam pembentukan konsep dirinya. Guru harus bijak dengan apa yang dikatakan dan dilakukan pada anak, sehingga tidak membuat anak merasa tidak berarti, tetapi justru menjadikan anak lebih dapat mengembangkan keterampilannya yang akan mempengaruhi harga dirinya.

Penelitian Ulfah (2007) dengan latar belakang di Indonesia memeriksa bagaimana peran persepsi keharmonisan keluarga dan konsep diri terhadap kecenderungan kenakalan remaja dan anak masa kanak-kanak akhir. Hasil penelitian menunjukkan bahwa konsep diri yang rendah dan peran keluarga yang rendah berhubungan dengan kecenderungan kenakalan dari anak dan remaja yang tinggi. Sebaliknya konsep diri dan peran keharmonisa keluarga yang tinggi berhubungan dengan rendahnya tingkat kenakalan remaja. Sederet fakta di atas menunjukkan bahwa konsep diri berkaitan erat dengan orang-orang terdekat serta komunitas di sekitar anak. Menciptakan lingkungan keluarga dan masyarakat yang kondusif serta penuh nilai positif diharap mampu membantu pembentukan konsep diri positif yang dibutuhkan anak pada masa kanak-kanak akhir untuk transisi ke masa remaja yang memiliki beragam tantangan perkembangan yang berbeda.

\section{SIMPULAN DAN SARAN}

Kajian terhadap literatur menunjukkan konsep diri merupakan variabel kompleks yang memiliki beragam faktor, aspek dan dimensi yang mempengaruhi. Konsep diri anak sendiri ditentukan oleh beberapa aspek seperti kemampuan fisik, penampilan fisik, hubungan dengan lawan jenis, hubungan dengan sesama jenis, hubungan dengan orangtua, kemampuan matematika, kemampuan verbal, performansi di sekolah secara umum dan konsep diri secara umum. Penelitian yang ingin mengeksplorasi konsep diri anak diharapkan mempertimbangkan aspek-aspek menurut Shalvelson tersebut. Eksplorasi terhadap konsep diri yang terdapat diri anak akan membantu akan mengembangkan perilaku yang positif dan mudah diterima oleh lingkungannya. Hal tersebut diperlukan oleh semua anak, termasuk pada anak usia dini dengan disabilitas, yang membutuhkan konsep diri yang baik untuk dapat mengembangkan kemampuan sosial mereka (Harry, Bunga, \& Kiling, 2015). 


\section{DAFTAR RUJUKAN}

Adiyanti, M. G. (2007). Konsep Diri Positif, menentukan prestasi anak. Yogyakarta: Kanisius.

Alwisol. (2012). Psikologi Kepribadian, Malang : UMM.

Burns, R. B., (1979). The Self Concept : Theory, Measurement, Development and Behavior, London: Longman Group Limited.

Byrne, B.M \& Gavin, D. A. W. (1996). The Shalvelson Model Revisited : Testing for the Structure of Academic Sef-Concept Across Pre-, Early, and Late Adolescents. Journal of Educational Psychology, 88(2), 215-228.

Calhoun, J.F \& Acocella, J. R. (1990). Psychology of Adjustment and Human Relationships. New York: Mc GrawHill.

Ganur, M. H., Bunga, B. N., \& Kiling, I. Y. (2014). Pola komunikasi anak usia dini tunarungu bukan bawaan. Jurnal Transformasi Edukasi, 3(2), 63-69.

Gunarsa, S. D., \& Gunarsa, Y. S. D. (2006). Psikologi Perkembangan Anak dan Remaja. Jakarta: BPK Gunung Mulia.

Harry, G. A. A., Bunga, B. N., \& Kiling, I. Y. (2015). Perkembangan sosial pada anak tunarungu yang belum bersekolah. Jurnal Transformasi Edukasi, 4(1), 1-7.

Hurlock, E. B. (2013). Perkembangan Anak. Jakarta: Erlangga.

Johnson, R. C. and Medinnuss, G. R. (1974). Child Psychology, Behavior and Development, Canada: Wiley International Edition.

Marsh, W. H., Relich, J. D., \& Smith, I. D. (1983). Self-Concept: The Construct Validity of Interpretations Based Upon the SDQ. Journal of Personality and Social Psychology, 45(1), 173-187.

Mussen, P. H., Conger, J. J., Kagan, J., \& Huston, C. A. (1979). Child Development and Personality, $5^{\text {th }}$ Ed. New York : New York Harper \& Row Publisher.

Puspasari, A. (2007). Mengukur Konsep Diri Anak, Cara Praktis bagi Orangtua untuk Mengukur dan Mengembangkan Konsep Diri Anak. Jakarta: Alex Media Komputindo.
Salbiah. (2003). Konsep Diri. USU digital Library.

Santrock, J. W. (2014). Life-Span Development, New York. McGraw-Hill College.

Song, I-S., \& Hattie, J. (1984). Home Environment, Self Concept and Academic Achievement: A causal Modeling Approach, Journal of Educational Psychology, 76(6), 269-281.

Spilsbury, J. C. (2002). "If I don't know them, I'll get killed probably": How children's concerns safety shape help seeking behavior. Childhood, 9(1), 101-117.

Susana, T. (2007). Konsep Diri Positif, menentukan prestasi anak. Yogyakarta: Kanisius.

Ulfah, M. (2007). Peran persepsi keharmonisan keluarga dan konsep diri terhadap kecenderungan kenakalan remaja. Tesis. Yogyakarta: Universitas Gadjah Mada.

Wyse, D. (2009). Childhood Studies: an Introduction. Australia: Blackwell Publishing. 